\title{
The Precautionary Principle and the Environment: A Case Study of an Immediate Global Response to the Molina and Rowland Warning
}

Kathryn Willi, ${ }^{1}$ A. R. Ravishankara,,${ }^{1,2}{ }^{*}$ Guus J.M. Velders,,${ }^{3,4}$ John S. Daniel, ${ }^{5}$ Mack McFarland, ${ }^{6}$ and Stephen O. Andersen ${ }^{7}$

1: Department of Chemistry, Colorado State University, Fort Collins, CO, 80523, USA

2: Department of Atmospheric Science, Colorado State University, Fort Collins, CO, 80523, USA

3. National Institute for Public Health and the Environment (RIVM), P.O. Box 1, 3720 BA Bilthoven, The Netherlands

4 Institute for Marine and Atmospheric Research Utrecht, Utrecht University, Utrecht, The Netherlands

5: NOAA Chemical Sciences Laboratory (CSL), 325 Broadway, Boulder, CO, 80305 USA

6: DuPont Fluorochemicals, Wilmington, DE 19805. ${ }^{\mathrm{a}}$

7. Institute for Governance \& Sustainable Development (IGSD), 2300 Wisconsin Ave. NW, 300B

Washington, DC 20007, USA

*Address correspondence to: A.R.Ravishankara@colostate.edu

a: Retired from DuPont Company; Fluorochemicals business was split off as part of The Chemours Co. before retirement.

\section{Supplementary Information:}

The SI contains the calculated release fraction as a function of the year subsequent to its consumption. This release function was calculated in this work and is different from those used in various assessment, as described in the manuscript. The SI also list the acronym used in this paper. 
The calculated release fractions since production, the banking times, are shown in Figure S1 below.

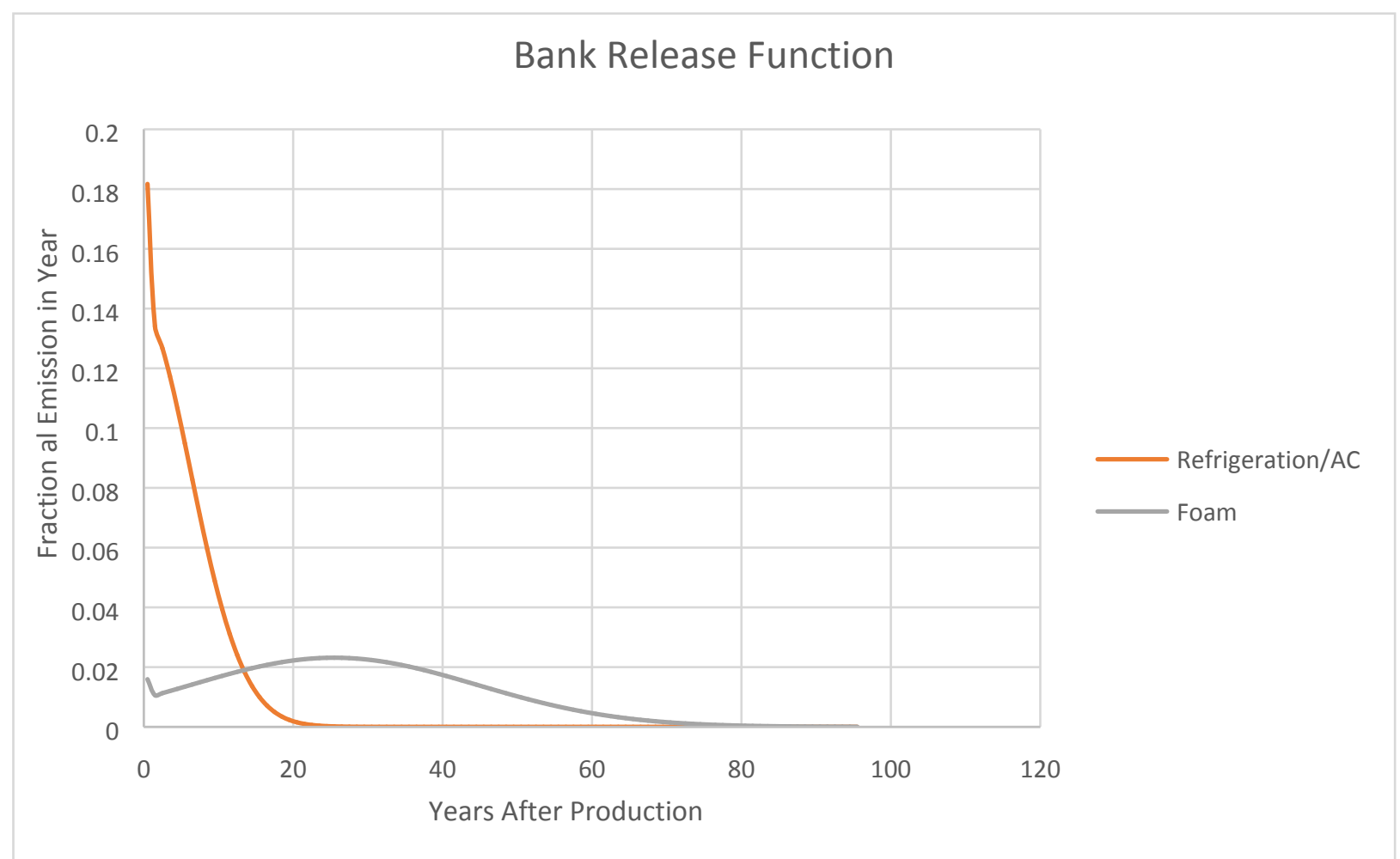

Supplementary Figure 1. Bank release functions for the two banked applications: (1) refrigeration and air conditioning (category 2) and (2) closed-cell foams (category 1 ). The open cell and aerosol/solvent use (category 3 ) emit what is produced in the same year. The least-squares retrieval discussed in the text assumes a Gaussian form for the release function. A separately retrieved fractional amount of production is emitted in the first year for each application. Release functions are the same for CFC-11 and CFC-12. 


\section{Acronyms}

$\begin{array}{ll}\text { AFEAS } & \text { alternative fluorocarbon environmental acceptability study } \\ \mathrm{C} & \text { Celsius } \\ \mathrm{CFC} & \text { chlorofluorocarbon } \\ \mathrm{CO}_{2} & \text { carbon dioxide } \\ \mathrm{CO}_{2} \text {-eq } & \text { carbon dioxide equivalent } \\ \text { EESC } & \text { equivalent effective stratospheric chlorine } \\ \text { EPA } & \text { US Environmental Protection Agency } \\ \text { EC } & \text { European Community } \\ \text { EU } & \text { European Union } \\ \text { GWP } & \text { global warming potential } \\ \text { HC } & \text { hydrocarbons } \\ \text { HCFC } & \text { hydrochlorofluorocarbon } \\ \text { HFC } & \text { hydrofluorocarbon } \\ \text { IPCC } & \text { Intergovernmental Panel on Climate Change } \\ \text { ISO } & \text { International Standards Organization } \\ \text { JARN } & \text { Japan Air Conditioning, Heating \& Refrigeration News } \\ \text { MLF } & \text { Multilateral Fund for the Implementation of the Montreal Protocol } \\ \text { NGO } & \text { non-governmental organization } \\ \text { ODP } & \text { ozone-depletion potential } \\ \text { ODS } & \text { ozone-depleting substance } \\ \text { RF } & \text { radiative forcing } \\ \text { SAP } & \text { Scientific Assessment Panel (of the UNEP Montreal Protocol) } \\ \text { SO } & \text { sulfur dioxide } \\ \text { UNEP } & \text { United Nations Environment Programme } \\ \text { UNFCCC } & \text { United Nations Framework Convention on Climate Change } \\ \text { UL } & \text { Underwriters Laboratories } \\ \text { WMO } & \text { World Meteorological Organization } \\ \end{array}$

